\title{
RBBP8 wt Allele
}

National Cancer Institute

\section{Source}

National Cancer Institute. RBBP8 wt Allele. NCI Thesaurus. Code C73441.

Human RBBP8 wild-type allele is located in the vicinity of $18 q 11.2$ and is approximately 93 $\mathrm{kb}$ in length. This allele, which encodes retinoblastoma binding protein 8 , plays a role in the modulation of both the cell cycle and cellular proliferation and may be involved in tumor suppression. Missense mutations in the gene are associated with pancreatic carcinoma. 